УДК 784.9.071.4

DOI:

Іван Фрайт, кандидат педагогічних наук, доцент кафедри народних музичних інструментів та вокалу Дрогобицького державного педагогічного університету імені Івана Франка Свгенія Шуневич, дочент кафедри народних музичних інструментів та вокалу Дрогобииького державного педагогічного університету імені Івана Франка

\title{
“МУЗИЧНО-ПЕДАГОГІЧНІ ПРИНЦИПИ ВОКАЛЬНОЇ ПЕДАГОГІКИ ВОЛОДИМИРИ ЧАЙКИ"
}

У статті розкрито музично-педагогічні принципи вокальної педагогіки Володимири Чайки. Встановлено, щуо ї̈ педагогічна діяльність базувалась на принципах вокальної педагогіки представників львівської та італійської вокальних шкіл. Здійснений аналіз виконавської і педагогічної діяльності співачки надав можливість дослідити спадкоємність педагогічно-виконавських традицій львівської вокальної школи.

Талановита оперна співачка, чудовий педагог і послідовник традииій своїх наставників Володимира Чайка зробила вагомий внесок у розвиток вокального мистецтва України.

Ключові слова: музично-педагогічні принципи; вокальна педагогіка; вокальна школа; педагогічна діяльність; концертна діяльність; виконавські традииї.

Jim. 5 .

Ivan Frait, Ph.D. (Pedagogy), Associate Professor of the Folk Musical Instruments and Vocals Department Drohobych Ivan Franko State Pedagogical University Eugene Shunevych, Associate Professor of the Folk Musical Instruments and Vocals Department Drohobych Ivan Franko State Pedagogical University

\section{"MUSICALAND PEDAGOGICAL PRINCIPLES OF VOCAL PEDAGOGY OF VOLODYMYRA CHAIKA"}

The article reveals the musical and pedagogical principles of vocal pedagogy of Volodymyra Chaika. It is established that her pedagogical activity was based on the principles of vocal pedagogy of representatives of Lviv and Italian vocal schools. In particular, the main musical and pedagogical principles of V. Chaika were: individual approach in the disclosure of natural abilities; combination of technical and artistic development of the vocalist; adherence to the sequence in the work on the development of the voice; naturalness of singing; preservation and development of timbre of the voice; sound on the support; use of resonators; achieving high sound emissions. Following the empirical method of teaching, which was typical of the Italian school, Volodymyra Chaika in practice presented the methods of correct vocal sound.

The analysis of the singer's performance and pedagogical activity provided an opportunity to explore the continuity of the pedagogical and performance traditions of the Lviv vocal school. Having received her musical education at the Ivan Franko University of Lviv at the Faculty of Philology and at the Mykola Lysenko Lviv Conservatory in the class of O. Bandrivska and P. Karmalyuk, Volodymyra Chaika became an unsurpassed performer of 42 vocal parts in 35 operas: Violetta (J. Verdi "Traviata "), Gilda (J. Verdi "Rigoletto"), Rozina (J. Rossini "Barber of Seville”), Leila (J. Bize "Pearl Seekers"), Adina (G. Donizetti “Love Drink"), Anna ("Don Juan" V. Mozart), Anthony, Olympia, Juliet ("Hoffmann's Tales" by J. Offenbach), Marilets ("Taras Bulba" by M. Lysenko), Nastka ("On Sunday morning the potion dug" by V. Kireiko). Her repertoire also included vocal Shevchenko and solo songs by M. Lysenko. D. Sichinsky, J. Yaroslavenko, S. Lyudkevych, A. Kos-Anatolsky and others composers. Special attention of the singer's repertoire was paid to Ukrainian folk songs.

Talented opera singer, excellent teacher and follower of the traditions of his mentors Volodymyra Chaika has made a significant contribution to the development of vocal art in Ukraine. Thanks to her pedagogical abilities and vast experience, the opera singer brought up a new generation of professional singers.

Keywords: musical and pedagogical principles; vocal pedagogy; vocal school; pedagogical activity; concert activity; performing traditions.

П остановка проблеми. Музичнопедагогічна діяльність видатних співаків і виконавсько-педагогічні традиції західного регіону України займають особливе місце у загальному процесі розвитку музичної культури. Саме тому ці питання потребують подальшого осмислення і висвітлення. Значною мірою це стосується проблем, пов'язаних з історією розвитку професійного вокального мистецтва (виконавства 
і педагогіки) та формування львівської вокальної школи.

Як засвідчують наукові матеріали, львівська вокальна школа, як і українська вокальна школа загалом, синтезує в собі традиції італійського “бельканто”, “інструменталізм” - німецької, а також співочу речитативність російської вокальних шкіл. Це пояснюється тим, що традиції викладання сольного співу у Львові були багатогранними як щодо національних кадрів педагогів вокалу, так і методики його викладання. Дослідження вокальної культури західного регіону України, зокрема львівської вокальної школи, ії яскравих представників на сучасному етапі розвитку української музично-педагогічної науки потребує подальшого грунтовного вивчення висвітлення.

Наукові матеріали, які висвітлюють педагогічну діяльність і творчість Соломії Крушельницької, Одарки Бандрівської, Павла Кармалюка, Марії Байко, Тетяни Карпатської, видання репертуарних збірників Соломії Крушельницької, Марії Байко, Олександра Врабеля, Богдана Базиликута та інших, здійснених за останній час, доводять, що науковці зацікавлені дослідженням феномена львівської вокальної школи. Адже процес виховання співака-виконавця є складним і багатогранним, який поєднує в собі принципи вокальної педагогіки та вокального виконавства.

Пропонована стаття є доповненням до низки публікацій, в яких аналізуються репертуарні, методичні та педагогічні основи львівської вокальної школи, висвітлює основні біографічні відомості, творчий шлях та музично-педагогічні принципи вокальної педагогіки Володимири Чайки - яскравого представника львівської вокальної школи. Матеріалом для дослідження стало і узагальнення власних спостережень та висновків за період навчання у класі Володимири Чайки протягом 1990-1993 рр. Спілкування з педагогом у період та після завершення навчання, ознайомлення 3 її особистим архівом - це науковий доробок, який потребує висвітлення.

Аналіз останніх досліджень та публікацій. Проблеми становлення та розвитку львівської вокальної школи висвітлені у працях Тереси і Лешека Мазеп, С. Павлишин, О. Бандрівської С. Вишневської, Л. Кияновської, А. Ковбасюка та ін. Надзвичайно цінним і найбільш грунтовним $\epsilon$ дисертаційне дослідження М. Жишкович “Львівська вокальна школа другої половини XIX - першої половини XX ст.” та численні статті авторки про видатних педагогів та співаків (В. Висоцького, О. Мишугу, О. Бандрівську, Л. Улуханову, Ч. Зарембу, М. Голинського,
О. Дарчука, I. Кушплера, О. Цигилика, А. Дашака та ін.).

До проблеми феномена Дрогобицької вокальної школи, її тісного зв'язку з львівською вокальною школою та їі яскравими представниками звертається Н. Сторонська у своєму дисертаційному дослідженні “Діяльність дрогобицької музичної школи в контексті українського академічного мистецтва (на прикладі Інституту музичного мистецтва Дрогобицького державного педагогічного університету імені Івана Франка)", де чітко виокремлено основні музично-педагогічні принципи, започатковані Миколою Копніним, який вважається основоположником вокальної виконавсько-педагогічної школи на Дрогобичині.

Мета статті - дослідити музично-педагогічні принципи вокальної педагогіки Володимири Чайки.

Виклад основного матеріалу. Володимира Павлівна Чайка народилася у селі Шили на Тернопільщині 2 квітня 1928 р. Батько Павло Слота був вчителем, володів грою на багатьох інструментах та навчав доньку гри на цитрі, мандоліні, гітарі. Після закінчення філологічного факультету Львівського університету імені Івана Франка працювала вчителькою української мови та літератури у середній школі № 63. Як згадує В. Чайка, - “декламація мимоволі переходила у спів”, тому у школі її називали “артисткою”.

У 1958 р. В. Чайка стала студенткою Львівської консерваторії у класі сольного співу Одарки Бандрівської, яка була ученицею Соломії Крушельницької та Софії Козловської. Аналіз наукових матеріалів дає можливість окреслити педагогічну складову її вокального навчання: від Валерія Висоцького (ученицею якого була Соломія Крушельницька), який зі свого боку був вихованцем Франческо Ламперті (італійська вокальна школа) та Генсбахера (німецька вокальна школа).

3 третього курсу В. Чайка навчається у класі Петра Кармалюка, який закінчив Київську консерваторію у класі відомого педагога Дмитра Євтушенка, учня Олени Муравйової. Як свідчать наукові матеріали, Олена Муравйова закінчила Московську консерваторію, iï педагогом була О. Олександра-Кочетова. Все це дає підставу зробити висновок, що на вокальне виховання Володимири Чайки великий вплив мала i російська вокальна школа.

Першою їі вокальною партією стає роль Настусі в опері М. Вереківського "Сотник”, пізніше вокальнапартія уопері “Алєко”С.Рахманінова, опері “Ноктюрн” М. Лисенка, опері “Запорожець за Дунаєм" С. Гулака-Артемовського. Як свідчать наукові матеріали, у вокальній партії 
Марильці (“Тарас Бульба" М. Лисенка) проявились блискучі вокальні здібності співачки, а також іï акторські дані. Дипломною роботою стала вокальна партія Віолетти в опері “Травіата" Дж. Верді. Цю партію В. Чайка $з$ успіхом виконувала сотні разів на різних концертних сценах.

Після закінчення консерваторії у 1963 р. вона стає солісткою Львівського оперного театру. В. Чайка відзначалась великою працездатністю. Зокрема, протягом першого сезону вона вивчила вісім нових вокальних партій. Численні наукові матеріали наголошують не тільки на тї вокальній майстерності, а й на майстерності драматичної гри на сцені. Вокальні партії у операх “Ріголетто", “Дон Карлос” Дж. Верді, “Богема” Дж. Пуччіні, “Кармен” та “Шукачі перлів” Ж. Бізе, “Севільський цирульник” Дж. Россіні стали чудовими зразками їі блискучої вокальної техніки, майстерного акторського перевтілення та жіночої краси. Часто Володимира Чайка співала поруч зі своїм педагогом П. Кармалюком, який любив співати зі своїми учнями. В окремих виставах, наприклад, "Шукачі перлів" та "Ріголетто" всі партії виконувались винятково його вихованці.

Володимира Чайка стала неперевершеною виконавицею 42 вокальних партій у 35 операх: Віолетта (“Травіата" Дж. Верді), Джильда ("Ріголетто" Дж. Верді), Розіна (“Севільський цирульник” Дж. Россіні), Лейла (“Шукачі перлів” Ж. Бізе), Адіна (“Любовний напій” Г. Доніцетті), Анна (“Дон Жуан” В. Моцарта), Антонія, Олімпія, Джульєтта ("Казки Гофмана" Ж. Оффенбаха), Марильця (“Тарас Бульба” М. Лисенка), Настка (“У неділю рано зілля копала” В. Кирейка). У іiі репертуарі були також вокальна шевченкіана, солоспіви М. Лисенка. Д. Січинського, Я. Ярославенка, С. Людкевича, А. Кос-Анатольського та інших композиторів. Особлива увага в репертуарному розмаїтті співачки надавалась українській народній пісні. П. Медведик відзначає: “Кожна арія у їі виконанні малює перед слухачем виразно окреслений образ, глибинно ніжний, овіяний теплотою і українською щирістю, чарівною жіночністю. Найбільше боӥться співачка викликати жаль до своїх героїнь, переповнених стражданнями від нерозділеного чи зрадливого кохання" [5].

Таким чином, можна зробити висновок, що у концертній діяльності В. Чайки простежується спадкоємність репертуарних традицій С. Крушельницької, О. Бандрівської, П. Кармалюка. Це, зокрема, проявилось в опорі на класичні оперні зразки, романсово-пісенну спадщину (твори М. Лисенка, Д. Січинського, Я. Лопатинського,
В. Косенка, А. Кос-Анатольського, С. Людкевича, Р. Шумана. Ф. Шуберта), а також на українську народну пісню.

Необхідно відзначити, що концертні виступи співачки з успіхом проходили “не лише в Україні, але й за кордоном. Географія виступів артистки охоплює Угорщину, Югославію, Польщу, Грузію, Росію, Німеччину, Чехію, Болгарію, Монголію, Америку, Канаду. Брала активну участь в декадах українського мистецтва, що проходили в Азербайджані (Баку), Росії (Омськ, Томськ, Тюмень, Сибір), в країнах Прибалтики" [3, 159].

Аналізуючи вокальну творчість Володимири Чайки, відзначимо певну закономірність кращих рис ㄲï педагогів. Це, зокрема, величезна насиченість і різноманітність репертуару, використання поряд 3 принципами української вокальної школи (розвиток тембрального багатства голосу, мистецтво передачі образної сфери) прогресивних засад італійської, німецької та російської вокальних шкіл. У численних схвальних відгуках на її виступи (1963-1980) відзначається високий рівень їі вокальновиконавської та акторської майстерності: володіння чіткою дикцією, широким діапазоном, вивіреним жестом, переконливістю у передачі образно-чуттєвої сфери, різноплановістю характерів ії героїнь - ліричних, трагічних, веселих, комічних.

31 вересня 1991 р. В. Чайку було прийнято на посаду доцента кафедри сольного співу Львівської консерваторії, у 2001 р. вона стає професором цієї ж кафедри. В основу своєї педагогічної діяльності В. Чайка поклала кращі принципи вокальної педагогіки свого вчителя П. Кармалюка, які грунтувались на поєднанні природних голосових даних, досконалому володінні вокальнотехнічними навичками, вивченні досвіду видатних співаків, ознайомленні з принципами акторської майстерності, де вокально-музична канва підпорядковується правдивості драматургії [4, 87].

Аналіз наукових матеріалів дає можливість стверджувати, що основними музичнопедагогічними принципами вокальної педагогіки В. Чайки стали: індивідуальний підхід у розкритті природних здібностей; поєднання технічного i художнього розвитку вокаліста; дотримання послідовності у роботі над розвитком голосу; природність співу; збереження і розвиток тембрального забарвлення голосу; звучання на опорі; використання резонаторів; досягнення високої звукової емісії. Вона дотримувалась емпіричного способу навчання, який був характерним для італійської школи. В. Чайка на практиці показувала правильне звучання, тобто 
як потрібно співати. На думку О. Бандрівської, цей метод “був надзвичайно переконливим, бо... молоді вокалісти не вміють себе слухати самокритично" $[1,8]$.

У роботі над голосом В. Чайка вимагала округлого, близького, дзвінкого звуку, рівного у всіх регістрах, тембрально багатого, співу “під куполом”, утримання стану “напівпозіху”. Як педагог вона наполягала, щоб у кожну ноту, фразу, слово студент вкладав власну думку, бо від цього залежить виконання твору. Завжди вимагала осмисленого співу, глибокого розуміння образу, характеру.

Маючи величезний виконавський досвід, добрий вокальний слух, В. Чайка спрямовувала студента на вірний шлях розуміння твору, не нав'язуючи своєї трактовки, нюансування, виконавської манери. У роботі над романсами і народними піснями рекомендувала завжди відштовхуватись від поетичного тексту.

Наукові матеріали свідчать, що у педагогічній діяльності В. Чайка великого значення надавала виробленню вокально-технічних навичок у студентів, тому завжди індивідуально для кожного підбирала комплекс вправ і вокалізів за принципом зростання складності та розширення співацького діапазону, ускладнення метро-ритмічних малюнків, урізноманітнення штрихів. Особливу увагу в роботі зі студентами вона приділяла вирівнюванню діапазону, згладжуванню регістрових переходів, що великою мірою вливало на професійне звучання голосу. Відомий педагог П. Голубєв 3 цього приводу зазначав: “Наполеглива робота над вирівнюванням регістрів майже завжди відкриває шлях до нормального розширення діапазону найбільш якісних звуків голосу, тому що неможливо проспівати всі звуки свого діапазону за допомогою того самого механізму гортані" $[2,30]$.

Слід відзначити, що у педагогічній діяльності В. Чайки прослідковується збереження основних методичних принципів формування співакавиконавця на основі традицій львівської вокальної школи. У 2002 р. вона видала монографічномемуарну працю “Павло Кармалюк: життя та творчість актора, співака, вчителя”, намагаючись розкрити та зберегти методичні засади свого педагога. В. Чайка $є$ автором і методичного посібника “Мистецтво творити співом”, в якому розкрито значення психофізичного стану студента у розвитку його вокальної майстерності.

Завдяки педагогічним здібностям та величезному досвіду оперної співачки В. Чайка виховала нове покоління співаків-професіоналів, серед їі випускників є лауреати міжнародних конкурсів: М. Рудь - лауреат міжнародного конкурсу імені А. Сарі (Польща), Н. Кузьменко лауреат міжнародного конкурсу імені Ружицького (Польща) та інші.

Висновки. Аналіз вокальної техніки сучасних співаків з позицій вокальної педагогіки підтверджує думку про те, що володіння вокальною методикою $\epsilon$ необхідною умовою, вона забезпечує співакові можливість реалізації своїх художніх намірів, і дозволяє визначити основні складові правильного співу.

У своїй педагогічній діяльності В. Чайка зуміла поєднати знання, здобуті у своїх вчителів О. Бандрівської та П. Кармалюка, і власний акторсько-виконавський досвід, пристосовуючи їх до конкретних умов навчального процесу. Вона була переконана, що успішний розвиток голосу i формування співака-виконавця залежить як від наявності яскравого мистецького хисту, так і від фізіологічних компонентів - свідомої мінімізації всіх фізичних зусиль, пов'язаних зі звукоутворення.

Талановита оперна співачка, прекрасний педагог і послідовник традицій своїх наставників В. Чайка стала яскравим представником духовної еліти України, вона гідно відстоювала професіоналізм і відродження вокальної культури українського народу.

\section{ЛІТЕРАТУРА}

1. Бандрівська О. Науково-методичні праці, статті, рецензії: наукові збірки ЛДМА ім. М. Лисенка. Вип.6. Львів, 2002. $147 \mathrm{c}$.

2. Голубєв П. Поради молодим вокалістам. Київ: Музична Україна,1983. 62 с.

3. Жишкович М. Ї̈̈ душа - то чайка над водою... Українська музика. 2016. № 1 (19). С.154-160.

4. Кияновська Л. Стильова еволюція галицької музичної культури XIX-XX ст.: Монографія. Тернопіль: Астон, 2000.339 c.

5. Медведик П. Творче небо Чайки. Вільне життя. 1978. 21 травня.

\section{REFERENCES}

1. Bandrivska, O. (2002). Naukovo-metodychni pratsi, statti, retsenzii [Scientific and methodical works, articles, reviews]. Lviv, 147 p. [in Ukrainian].

2. Holubiev, P. (1983). Porady molodym vokalistam [Tips for young vocalists]. Kyiv, 62 p. [in Ukrainian].

3. Zhyshkovych, M. (2016). Yii dusha - to chaika nad vodoiu... [Her soul is a seagull over the water]. Kyiv, pp.154-160. [in Ukrainian].

4. Kyianovska, L. (2000). Stylova evoliutsiia halytskoi muzychnoi kultury XIX-XX st. [Stylistic evolution of Galician musical culture of the XIX-XX centuries]. Ternopil, 339 p. [in Ukrainian].

5. Medvedyk, P. (1978). Tvorche nebo Chaiky [Creative sky Seagulls]. Ternopil. [in Ukrainian].

Стаття надійшла до редакції 15.03.2021 